\title{
Consecrated Ground: Spatial Exclusion And The Black Urban Body
}

\author{
Domenico A. Beneventi*
}

\begin{abstract}
Resumo
This article focuses on the exclusion suffered by black communities in Canada since colonial times. Segregationist policies imposed by white settlers endorsed, among other factors, fears of touching, defilement, and the corruption of racial purity, thus aggravating both spatial and social exclusion of black communities. In fact, hegemonic colonialist discourse has often correlated the colour black and the abject, associating blackness with the excretions of the body. One example is the black township of Africville, where precarious spaces have been ascribed to black bodies. It may be said that the Canadian spatial imagery is a mainstream construction, aimed at excluding all threats to the privileged white body. Examples of criticism to the dehumanization practices generated by such policies abound on the literary works by Austin Clarke, George Elliott Clarke, and Makeda Silvera, in which the construction of a black body in Canadian urban space is proposed.

Palavras-chave: African Canadian literature. Blackness. Africville. Spatial exclusion. Urban black body.
\end{abstract}

There has been a long history of discrimination, exclusion, and racial segregation of Canada's black communities. The establishment and growth of the slave trade, enabled by European maritime technology, made it economically feasible and efficient to establish a trade network of slaves between Africa and the New World. Labour supply in the Americas was affected not only by the lack of Native Americans' immunity to European diseases, but by European workers' inability to contend with the extreme heat and tropical diseases in the South American colonies. James Walker argues that, contrary to the prevalent understanding that the slave trade was justified by a racialized discourse that constructed the black body as inferior to that of whites, "it was the superiority of African labourers in the New World tropics that sealed their fate as slaves" (WALKER, 1999, p.140).

* Université de Sherbrooke, Canada. 
While there were approximately 1,400 slaves in New France before the conquest, they arrived through the British West Indies or through the American colonies in the South. The "Black Loyalists" arrived in Nova Scotia in 1783, attracted to the British colonies at the North by "the expectation that they would be accorded completely equal treatment with their white counterparts" (WALKER, 1999, p. 142). But such hope for equality was unrealized, since "their civil rights were curtailed and there were many restrictions imposed on them by a white majority that considered them more suitable for slavery than for equality" (WALKER, 1999, p. 142). Despite White Loyalists' overt racism and refusal to grant basic human rights to blacks, they welcomed the arrival of the "Maroons" from Jamaica, since "black labour was vital to pioneer enterprise in the Maritimes" (WALKER, 1999, p. 142). They established communities that were spatially segregated from whites until they migrated back to Africa in order to found Sierra Leone in 1800. Following a second influx of blacks after the American War of 1812, the assembly of Nova Scotia attempted to stop all subsequent black migration. It must be remembered that at this point in Canadian history, the black population consisted of a combination of slaves, black Loyalists, and refugees from the American South. Blacks fared no better in the West, for while they were present as "fur traders, cowboys, [and] broncobusters" (WALKER, 1999, p. 144), their increasing number provoked a hostile response from whites. As a result, "public petitions and municipal resolutions from all three Western provinces urged Ottawa to ban further black immigrants and to segregate those already there" (WALKER, 1999, p. 144). Due to fears that a legislative ban on black migration could negatively affect Canadian-American relations and raise the ire of AfricanCanadians in Ontario and the Maritimes, "less overt measures were adopted" (WALKER, 1999, p. 144) in discriminating against them. For instance, Canadian government agents were sent into the American South to discourage black migration, and "medical, character, and financial examinations" were rigorously applied at border crossings [denying] black passengers entrance into Canada" (WALKER, 1999, p. 144). A clause written into the Immigration Act of 1910 denied entrance to "immigrants belonging to any race deemed unsuited to the climate or requirements of Canada" (WALKER, 1999, p. 144). While amendments to the Immigration Act in 1952 changed the terms from "race" to "ethnicity," Walker points out that "the Supreme Court of Canada interpreted the two terms to mean the same thing and validated exclusion of prospective immigrants because of their "race"' (WALKER, 1999, p. 144). 
While they were always a small minority in Canada, particularly before the 1960s, "African Canadians participated in the original settlement of almost every region and major city in Canada," including Montréal, Halifax, and "virtually all the Loyalist communities" (WALKER, 1999, p. 145). Despite the fact that three separate armed corps of blacks won white approval for their "readiness to defend the Empire" (WALKER, 1999, p. 146) with their lives, black refugees were rewarded with inadequate farmland "too small to sustain economic independence" (WALKER, 1999, p. 146). In Montréal and Toronto, housing discrimination directed black communities to areas bordering railway yards, black churches, and the "least expensive districts" (WALKER, 1999, p. 148) of the city. Census reports and immigration statistics were also deliberately used as a weapon in excluding blacks in Canada through their "deliberate effort to underestimate the black population" (WALKER, 1999, p.148). Blacks were understood as belonging at the bottom of the socio-economic scale, below other incoming immigrant groups and Native populations, and when jobs were scarce, white ire was directed against them, culminating in violence, the destruction of black churches, and physical expulsion. Thus, by the time of confederation, "economic circumstances and the precedent set by slavery had relegated most African-Canadians to a service and labouring role; a 'place' had been allotted for blacks consistent with prevailing social considerations" (WALKER, 1999, p. 150). African-Canadians were forced to occupy spaces in the city and in the workforce, which strengthened their image as servile to whites (as domestics, porters, and manual labourers, for instance). These exclusionary employment and housing policies, seen also in the Chinese community in Vancouver, ensured that (black) visible minorities were unable to challenge the existing social-economic hierarchies of city and nation. A perverse effect of these exclusionary and racist policies is that eventually these communities come to be associated with the abject materials (laundry, food, dirt, domestic wastes) that they touched. The "servile black body" is thus produced by a white racist discourse that attempted to keep the "defiling other" at arm's length.

After the American Civil War, blacks fleeing north did not escape racial prejudices that constructed them as fugitives "tainted by slavery" (WALKER, 1999, p. 152). As we shall see in the literature of "Africadia" the mobile black body of "runaway slave" narratives is reconfigured by later poets and writers into a body rendered criminal by virtue of its urban mobility in a predominantly white city. ${ }^{1}$

1 This term was coined by George Elliott Clarke, who writes in the "Confession" to Fire on the Water: 
The intersections of race and gender discourses demonstrate how important it was for the white majority, on the one hand, and males on the other, to sustain their own centrality in the economic, social, and symbolic power networks of the nation. While white women were relegated to the home in the "cult of domesticity," black women, because of economic necessity, were forced to be wage earners outside the home and were consequently better educated in general than black men. This departure from the usual spatial constraints imposed on women comes to be seen as an aberration by the white middle class, one attributed to the transgressive nature of black identity: "What black families had grown used to as interdependency struck white observers as odd and unnatural; black women were depicted as masculine, black men as weak and ineffectual for their failure to support their partners, the black family as matriarchal and dysfunctional" (WALKER, 1999, p. 155).

The segregationist policies imposed on black communities in Canada were indicative of underlying fears of touching, defilement, and of the corruption of racial purity. For instance, movie theatres in Montréal and residential neighbourhoods in Calgary were segregated according to race (WALKER, 1999, p.155). Racially segregated schools ensured that economically destitute black communities remained so, since its students acquired a generally lower quality of education. This ensured that "black children did not generally receive an education equivalent to that obtained by whites; they entered the workforce with inferior qualifications, which limited their occupational horizons, their incomes, and their status in the broader society" (WALKER, 1999, p. 160). Despite new patterns of black immigration in the 1960s in which highly educated individuals arrived from the various nations of the Caribbean, these groups continued to suffer from various forms of racist discourse and exclusion.

Some of the most widespread discrimination occurred in public accommodations, transportation, and places of entertainment. Hotels, saloons, lake steamers, stagecoaches, and theatres in the Maritimes, Ontario, and the West habitually refused service to blacks or relegated them to segregated facilities. Occasionally, racial separation was enforced by mob violence. (WALKER, 1999, p. 164) While white mobs cite racial and national purity as a way of justifying

"I use the term 'Africadian,' a word I have minted from 'Africa' and 'Acadia' (the old name for Nova Scotia and New Brunswick), to denote the Black populations of the Maritimes and especially of Nova Scotia. Other appellations - 'Afro-Nova Scotian, 'Black Nova Scotian,' etc. - are unwieldy. Moreover, if Africadians constitute a state, let it be titled Africadia” (CLARKE, 1995, p. 8). 
the exclusion of blacks, white panic over unbridled black sexuality instigated the "Imperial Order of Daughters of the Empire" to ask that "blacks be kept out or white women would not be safe" (WALKER, 1999, p. 166). They warned, "lynching would occur if the government did not act to protect white womanhood" (WALKER, 1999, p. 166). Even black war veterans did not escape segregationist policies, as their bodily remains were interred in a black-only section of the Camp Hill military cemetery in Halifax (WALKER, 1999, p. 165).

Black communities, however, resisted the "place" that had been imposed upon them within the hierarchy of Canadian society. African Canadians "seized the rhetoric of British rights to assert their demand for equality" (WALKER, 1999, p. 164), for as taxpayers they were entitled to the same quality of education as whites. Contrary to the mythology of an open and inclusive society, Walker points out that racial exclusion and black segregation were perfectly legal under Canadian Law until the 1940s, when the Supreme Court of Canada ruled otherwise, which only came at the cost of considerable pressure from various black political organizations and church groups across the country.

Despite common belief to the contrary, the history of blacks in Canada has not been characterized by multicultural acceptance or inclusiveness. From the historical disavowal of slavery to tensions emerging from racial profiling, the black body in Canada has consistently been spatially and socially excluded, put under constant surveillance as a threat to middle-class civility and characterized as a contaminant to its cultural hegemony.

\section{Constructing Blackness}

"Blackness" has traditionally been signified negatively in the black/white binary, constructed as either that which lacks civilization or, obversely, that which defiles the civilized. This binary has been employed in spatial discourses and practices that seek to exclude racial others or otherwise relegate them to subordinate social spheres. Used extensively as justification for the enslavement of "dark" races, these colours (black/white) are "readily associated with defilement and purity" (SIBLEY, 1995, p. 22), and have been central to the "process of regulating and dominating the colonized" (SIBLEY, 1995, p. 19). In terms of colonial/postcolonial identity and political agency, the colour black has consistently been constructed as the abject in the language of purity and defilement: ${ }^{2}$

2 Frantz Fanon's Black Skins White Masks, Edward Said's Orientalism, Homi Bhabha's The Location of Culture, and Bell Hooks' Yearning: Race, Gender, and Cultural Politics are all seminal 
In white Northern European cultures, associations with dirt, blackness and nature have created negative stereotypes of Africans, Afro-Caribbeans, people from the Indian subcontinent, and Gypsies, by informing constructions of national identity that omit these groups and representing them as threatening. Their abjection is related to colonial histories but also to those things that threaten the boundaries of the (white) body and with which colonial minorities have been elided in the process of dehumanizing them. White signifies both purity and order and black signifies defilement and disorder in racist discourse, so representations of blackness create anxieties about borders - of the body, the neighbourhood, and the nation - which are deeply rooted in states with colonial experiences. (SIBLEY, 1995, p. 124).

Black bodies are symbolically associated with all the negative implications, which the colour itself has given rise to, in the history of Western civilization, including death, a "source of defilement, a state which threatens life, and of the corpse, which signifies decay and contagion" (SIBLEY, 1995, p. 22). Black has also been closely associated with fear of darkness and with the unknown. This is particularly true in an urban context, where the black body, particularly the youthful male black body, has been associated with the criminal and the transgressive. The negative associations of blackness, concomitant with fears about darkness, render the black nocturnal body the most dangerous form of urban corporeality: "the association between black and dirt, between dirt and disease, emphasizes the threatening quality of blackness. Removing blackness, injecting light, removes fear, but this fear may be a fear of others as much as a fear of darkness" (SIBLEY, 1995, p. 23). If blackness is the abject, that "unseen" which must be symbolically evacuated, it is also, ironically, the "all-too visible." The black body in white space is invisible in terms of the imaginary geography of the nation, but "hyper-visible" (WALCOTT, 2003, p. 44) to those who see such a body as a threat that must be kept under constant surveillance.

Frantz Fanon sees blackness as being tied to relations of domination, a "direct result of colonialist subjugation" (FANON, 1967, p. 17) and its concomitant "epiduralization of inferiority" (FANON, 1967, p. 11). The "myth of the bad nigger" (FANON, 1967, p. 92) is tied to relations of domination between colonizer and colonized in which the black body takes its consistency, its definition even,

works which discusses "blackness" in relation to (post)colonialism, nationalism, and subaltern identity politics. 
as the abject - its condition of being "caught" by the white gaze and thrust aside, expelled, and fixed into objecthood:

I move slowly in the world, accustomed now to seek no longer for upheaval. I progress by crawling. And already I am being dissected under white eyes, the only real eyes. I am fixed. Having adjusted their microtomes, they objectively cut away slices of my reality. I am laid bare. I feel, I see in those white faces that it is not a new man who has come in, but a new kind of man, a new genus. Why, it's a Negro! (FANON, 1967, p. 116).

Blackness is also associated with the excretions of the body. Laporte writes that "to the white man, the black man has the colour and odour of shit" (LAPORTE, 1993, p. 59), and their mutual hatred is based on "a reciprocal recognition: the white man hates the black man for exposing that masked and hidden part of himself. The black man hates the white man's need to pull himself up from the earth" (LAPORTE, 1993, p. 59).

In the Canadian context, Rinaldo Walcott suggests that "writing blackness" has been difficult in this country for blacks have been "an absented presence always under erasure" (WALCOTT, 2003, p. 27). He refers here not only to the historical denial of slavery and the systemic racism operating in this country, but also to the erasure of the collective memory of the black communities of Atlantic Canada, which George Elliott Clarke resurrects under the banner of Africadia, his attempt to "map a black Canadian geography that is longer and older than the post 1950s black migrations from the Caribbean and more recently continental Africa" (CLARKE, 2002, p. 16). Both Walcott and Clarke attempt to revive the "missing" black body in Canadian space, restore it to the nation's spatial imaginary. "Blackness," like other formulations of ethnic or group identities, is a roving signifier, always subject to modification and change:

I mean to signal blackness as a sign, one that carries with it particular histories of resistance and domination. But blackness is also a sign which is never closed and always under construction ... [it] allows for a certain kind of malleability and open-endedness, which means that questions of blackness far exceed the categories of the biological and the ethnic. (WALCOTT, 2003, p. 27).

George Elliott larke argues that: 
Blackness remains an absolutely relative epistemology ... here the diversity of black communities proves that "black" is essentially a politically and culturally constructed category, which cannot be grounded in a set of fixed transcultural or transcendental racial categories and which therefore has no guarantees in Nature. In Canada, some are born black, some acquire blackness, and others have blackness thrust upon them. (CLARKE, 2002, p. 16).

Erin Manning similarly suggests that blackness functions as "the signifier of disappearance - that which is always out of sight, out of history, and out of circulation" (MANNING, 2003, p. 67). By excluding blackness from public discourse, by "placing blackness elsewhere," she argues, "Canadian history has and continues to obfuscate the black presence in Canada, which dates as far back as the sixteenth century" (MANNING, 2003, p. 67). Such forgetting and disavowal of black realities and histories in Canada ensure that blackness does not "divert attention from the white narrative of the 'founding fathers' (MANNING, 2003, p. 67). "What is ultimately at stake," writes Walcott, "is the space and place that bodies, both actual and symbolic, occupy in the nation's imagination. Black Canadian literature's unruly bodies will continue to insist upon a space where justice and freedom are possible" (WALCOTT, 2003, p. 54).

\section{Africville and the Racialization of Defilement}

One cannot speak of the physical, social, and symbolic exclusion of blacks in this country without mentioning Africville. A black township located on the outskirts of Halifax, Africville has become central to black constructions of Canadian space, for the forced evacuation of its residents was but one instance of the larger, systemic erasure and disavowal of the black experience in Canada, an attempt at "cleansing" Canadian territory of its non-white elements. With the destruction of Africville, Walcott argues, "the desire to render black peoples and blackness an absented presence in Canada has been made literally and symbolically clear" (WALCOTT, 2003, p. 44).

Africville became an area of the city in which the administration placed its undesirable industries and public works projects; slaughterhouses, tanneries, oil storage facilities, and a foundry encircled the township, while a prison and an infectious diseases hospital were established in the area. The city dump, incinerator, 
and railway lines also cut into Africville, and the various administrative strategies used to dehumanize its residents produced space as "a repository for all that the dominant group wanted to contain and distance itself from" (NELSON, 2002, p. 217). This includes not only all manner of industrial and domestic wastes garbage, refuse, and criminals - but blackness itself.

The denial of public services, adequate housing, and electricity produced a "self-fulfilling prophecy" (NELSON, 2002, p. 217) of destitution and failure, an urban slum which "legitimates dominance by offering a concrete example of filthy, intolerable conditions, a notion of helplessness and a lack of self-determination that are seen as inherent to its inhabitants" (NELSON, 2002, p. 217). As David Goldberg has suggested, slum or ghetto spaces are characterized by "dislocation, displacement, and division" and function to distance the social and spatial practices of dominant groups from subordinate ones. Slums are consequently "the primary mode by which the space of racial marginality has been articulated and reproduced" (GOLDBERG, 1993, p. 190). While this is also true in terms of class, it is particularly nefarious in the case of visible minorities in urban space, since the adverse economic environment of the ghetto and its general condition of neglect and poverty comes to be associated, in hegemonic public discourse, to the "degeneracy" of its residents: "The racial slum is doubly determined, for the metaphorical stigma of a black blotch on the cityscape bears the added connotations of moral degeneracy, natural inferiority, and repulsiveness" (GOLDBERG, 1993, p. 191). ${ }^{3}$

The writing that emanates from the Africville experience consequently constructs black urban bodies as residual and abject. In his poetry, David Woods describes how the residents of Africville "wander in bowed status" (WOODS, 2008, p. 135), slavish black bodies moving about in a white city with "minds estranged from themselves" (WOODS, 2008, p. 135) for they lack the education and opportunities available to whites. Africville is represented as a space in which violence, physical corruption, and death are commonplace, black bodies moving like "cadavers arranged like logs/ Moving along a stink river/ Not ours / but blowing on - lost forever" (WOODS, 2008, p. 136). In another poem titled "Harney Barton

3 This process of identification of an abjected other with their environment is similar to what Barnor Hesse has defined as "spatial nativization." Quoting Clifford, he argues that "people are compressed into prefabricated landscapes, the ghetto, the shanty town, and undergo a process of 'representational essentializing ... in which one part or aspect of people's lives come to epitomize them as a whole" (HESSE, 1993, p. 175). 
at the Tavern," the black body signals and is marked by a collective history of oppression as a drunk Barton performs a minstrel dance for his fellow bar mates:

\author{
He is a little ridiculous \\ But that does not matter, \\ His dance is understood by all those gathered, \\ From the sturdy labourers of Hammonds Plains, \\ To the young hookers from "the Square," \\ His feet tell their tales \\ Of simple lives gone wrong, \\ Of wasted beauty and ruined families \\ Of the simple and the poor- \\ Lost in an uncaring community. \\ (WOODS, 2008, p.138)
}

In George Elliott Clarke's "Campbell Road Church," Africville becomes a dream deferred, a promised land that is no longer attainable for it has been neglected and left to whither for too long by the city administration:

an ancient $\mathrm{CN}$ porter lusts for Africville beautiful Canaan of stained glass and faith made shacktown of shattered glass and shame rats rustling like a mayor's robe he rages to recall the gutting death of his genealogy to protest his home's slaughter by butcher bulldozers and city planners molesting statistics.

(CLARKE, 1995, p. 146)

In "Salvation Army Blues," poor black urban dwellers "stumble, punch-drunk / down these drawn and quartered streets / tense hands manacled / to empty pockets" (CLARKE, 1995, p. 150). The dire economic circumstances of the residents of Africville produces vagrant bodies that linger on the peripheries of the city - idle, and hence, suspect.

Frederick Ward presents a condensed history of the "slavish" black body occupying Canadian spaces, from the slave narrative of "Mary," who escapes the bondage of the American South, to the poor, homeless vagrants who must 
survive in the back alleys of Halifax's streets. Mary crosses the border from the United States into Canada armed only with "my fears and a hatchet" (WARD, 1995, p. 17). Her black slave-body, which is physically inspected by her owners who "checked my teeth ... snatched what be theirs from 'tween my legs to beat and chew on it" (WARD, 1995, p. 17), becomes a metonym of a black collective body suffering under the control of white racial injustice, raped by white claims on their bodies. Territory here becomes a source of physical danger, as Mary must hide her blackness from a threatening white space and the laws that govern it. Hers is Chang's notion of "runaway subjectivity", in which the ability to stay mobile in the face of a hostile environment becomes crucial to her survival, a theme which recurs also in the poetry of Gloria Wesley- Desmond: "Them dogs be chasin / My ol'man / see him runnin / Through the trees" (WESLEY-DESMOND, 1995, p. 70).

Just as the black slave-body must submit to the transgression of her bodily boundaries, the residents of Africville submit to the transgression of the familial home once the city administration decides to evict them. In "Dialogue \# 1," Ward relates the perceptions of an elderly black woman as she hears the first bulldozers begin their grim work of destroying the humble homes of Africville. She is visited by city inspectors who forcibly remove her and her belongings, entering her home, as follows:

like shadows come'd right round me. Come'd in here without asking pardon fer themselfs and took things from they place whilst I mumbled and pointed. I touched me breath and tried to slow them to take care. Some of them apologized fer moving me. But they made off with me evidence. I ACCEPTS! But I expects they'd least done the least, ceptin they ain't. THEY MOVED ME IN GARBAGE TRUCKS! (WESLEY-DESMOND, 1995, p. 19).

The dehumanization of the black (collective) body becomes necessary for the appropriation of their land, just as the construction of the Native as subhuman becomes necessary to colonial expansion and territorial appropriation. Furthermore, the equation is made between the garbage strewn in and around Africville, which may be seen as a necessary "residue" of white middle-class prosperity, and its black residents: 
Doggone thing's only been here a few years, and already people associate it with us. Or us with it. They take our school away and give us a friggin garbage dump! Well, when bad times hit you, you can just lay down and die. Or you can keep on goin' and make the best of it. So we try to make the dump work for us. Just because somebody throws something away, that don't mean you can't use it. Looks like a mountain of trash and junk, doesn't it? But it's not all bad. There's all kinds of scrap metal in there that you can collect and sell. (SAUNDERS, 1995, p. 62).

Like the Roma, the vagrant gypsies of Europe who are "generally represented as defiled or abject in relation to the culture of the majority because of the association between Gypsies and residual matter, like scrap metal" (SIBLEY, 1995, p. 121), the residents of Africville are associated to the refuse by which they are surrounded, becoming, at least in white middle-class minds, human garbage.

In a long poem entitled Back Alley Tramp, Gloria Wesley-Desmond shows the abject physical conditions of Africville, but also the difficulty of those who are transient, homeless women on its streets: “Alone, haunting the bleakness / Of the alley / Alone, except / For a few restless hungry / Creatures rubbing their Dirty backs over some / Over-turned can; and / Slinky rats speed along” (WESLEYDESMOND, 1995, p. 67). She rails against the "window pane stares / of people locked inside" (WESLEY-DESMOND, 1995, p. 67) for it is they who are to blame for her abject condition: "You gave me these boundaries - / Of alley dirt and fears / I'm your product / I'm your child / Your back alley tramp" (WESLEY-DESMOND, 1995, p. 67). Here the errant black body is "produced" by the racist discourses and practices which relegate her "polluting" black identity to the outside of the proper spatial contexts of home, security, and domesticity.

In A Visit to Africville, Charles Saunders writes that railroad tracks "slash through our community like a big pirate's sword” (SAUNDERS, 1995, p. 53). While the railway historically provided one of the few sources of employment for blacks in Canada, their visibility as porters relegated them to subservient positions in the community and produced the image of black bodies as servile. While black bodies are denied the spatial freedoms of whites, they are, ironically, allowed to travel across the continent as porters and servants on the trains: "Travelled all over Canada and down in the States, they did. Kept those sleepin' cars cleaner than the Sheraton Hotel. They'd come in their uniforms with the shiny brass buttons, and they'd be like heroes comin' back from the war. Best job a coloured man could get 
back in the old days" (SAUNDERS, 1995, p. 54). Just as Chinese labourers are allowed employment on steam ships that cross the Pacific, here blacks are allowed a regulated form of mobility tied to their economic and symbolic positioning at the bottom of the social hierarchy.

George Elliott Clarke describes Africville as the "long-gone 'slum by the dump' which the City of Halifax vomited beside Africville in the 1950's" (CLARKE, 2002, p. 289). The township here is described in terms of the abject, as that residual matter which a white city must expel if it is to assure the boundaries of its own collective identity. The eviction of the residents of Africville was justified by the city administration through arguments for sanitation, public health, and the welfare of its black residents. However, Clairmont and Magill argue that pressures within the white business community for lands to develop as industrial infrastructure at the outskirts of a growing city ultimately sealed the fate of the black community. Leslie Saunders recognizes that a marginalized black community "cut off from the structures and activities of urban Halifax" taints the space of Africville as "pre-modern," and its continued presence there "was an affront to the modern city that Halifax was becoming" (SAUNDERS, 1995, p. 108). Its destruction and complete removal from city maps in 1970 was "the culmination of a moral panic at the possibility of an independent, sovereign blackness" (NELSON, 2002, p. 231).

For Clarke, the evacuation and destruction of Africville represents "the ignoble and total defeat of the first Africadian nationalism - a silent, brooding, glimmering nationalism that represented, not the craving for a nation, but rather, the yearning for a space - a green space - in which the free self could be realized" (CLARKE, 2002, p. 293). Africville is described by Clarke as a mangled collective body suppressed from Canadian territory, a ghost which refuses to remain silent to injustice: "Africville itself was transformed into a cultural myth, the product of romanticism and nostalgia, a pays to mourn, a source of collective rituals ... the African Cultural Renaissance and its conscious nationalism are the dry bones which have put on flesh and wailed from the dust of Africville.'(CLARKE, 1995, p. 295).

In his own writing, Clarke attempts to "counter amnesia" by providing "a history of the black body and state violence in this country" (WALCOTT, 2003, p. 22). His Execution Poems was inspired by the true story of his cousins, George and Rufus Hamilton, who were hung in July of 1949 for the murder of a Fredericton taxi driver. In this collection, the black body is mangled by poverty, domestic 
and racial violence, and an unjust socio-economic environment. But the "truth" of this crime, Clarke seems to suggest, is one that has been too easily attributed to the inherently "criminal" nature of the black man, one which does not take into account a long history of social and economic oppression or the destitution which drives one to steal and murder. "Have you ever gone in your life, going / two days without eating, and whenever / you get money, you're gonna eat and eat / regardless of all the bastards in Fredericton" (CLARKE, 2001, p. 13). Execution Poems is discursively framed by Fanon's concept of négritude in its opening poem, "Negation" where the "meagre" black body in its "tarnished" corporeality is placed in contradistinction to the "shining" white body of "Her Majesty" (FANON, 1967, p. 11) the Queen, embodied metonym of law, justice, and the civilized. The narrator is that abjected other who is of little account in white eyes, "le nègre negated" (FANON, 1967, p. 11), a "whisky-coloured provincial, uncouth / Mouth spitting lies, vomit-lyrics, musty, Masticated scripture" (FANON, 1967, p. 11). The words of the "Negro" are likened to the abject, his "vomit-lyrics" to the expelling of that which offends. While the narrator is not a slave, his body metaphorically belongs to the Queen, for it falls under the purview of her colonial authority and is therefore fixed by her gaze. Nevertheless, he is "Her Majesty's Nasty, Nofaskoshan Negro" (FANON, 1967, p. 11), a modern-day Caliban who dares challenge the authority of his master. It is the narrator's "black face" that will "preface murder for you" (FANON, 1967, p. 11), suggesting a form of historical revisionism in which the black body is finally given voice - a counter-discourse to the "official" history of the crime included at the end of Execution Poems. This white take on black crime effaces the brothers' identities, showing only "the condemned men's shadows" (CLARKE, 2001, p. 44). By "speaking for" his absented cousins, Clarke attempts to resurrect their broken bodies in an Africadian spatial imaginary.

The various images of black bodies castigated, tortured, and cut away, of the blood of violence flowing freely throughout Execution Poems, reflects not only the realities of growing up in an environment of poverty, racial discrimination, and domestic violence, but also symbolizes the excision of black history and the black collective body from Atlantic Canada. It is a community in which women were "bullwhipped till blood/ lava'd down their backs and leapt off their heels/ was one hundred proof, fire taste of slavery" (CLARKE, 2001, p. 15). And while Rue wanted to be educated in the works by "Pushkin, Colette, E.B. Browning, and 
Alexandre Dumas - all those secretly Negro authors" (CLARKE, 2001, p. 17), he is instead educated in this: "A boy's right arm stuck to a desk with scissors; a father knifed in the gut while shaking hands with a buddy; two Christians slashed with gasoline and set ablaze in a church; a harlot garrotted in her bath" (CLARKE, 2001, p. 17). While the boys' father beat their mother for "he thought her being Mulatto/ was mutilation"(CLARKE, 2001, p. 16), their mother eventually, "fainted scrubbin some white house's blackened crap-box/ She got a heart stoppage and drooped, kaput" (CLARKE, 2001, p. 16). Perversely, she dies in a white home, bent to the task of cleaning the foulness produced by white middle-class bodies, abjected by her handling of residual matter.

The lack of opportunities for black Nova Scotians means that "Everywhere I saw a Crimea of crime, calamities of houses rigged from tar paper and rape, windows blinded with newsprint or burlap sacks. I could only start the stove with sparks and fear, watch yellow terror eating yesterday's bad news" (CLARKE, 2001, p. 17). It is a community of secrecy and closed doors, misery hidden away from public view:

Steps shear from beefy, rancid houses, T-bone into sidewalks. Or: ramshackle stars screw into air, then accordion into heaps of brickbroken bottles, trash, jalopy remains. Rubble architects the North End, some left over dying from '17's Explosion, when seamstresses got smashed by heavy machines crashing through floor after floor, and schoolkids' eyes shot out, gaudy with glass. A Canaan of syphilis: Halifax. (CLARKE, 2001, p. 23)

The black body in such abject conditions is "guttural," its face "makes a mess of light/ It's like a black splinter lancing snow" (CLARKE, 2001, p. 19). Indigo, a vagrant drunk, is described as "toxic, shabby, cross- eyed" (CLARKE, 2001, p. 23 ) as he takes out his anger on two small white boys who "accost him as n-i-gg-g-e-r" (CLARKE, 2001, p. 23), his revenge fantasy becoming savage breaching of corporeal boundaries and symbolic defilement of the white collective body:

Those two boys disintegrated under his blows, slicking them with red awfulness. Sampson holds two blond heads aloft like hauled-up weeds. He flings two fair splintered bodies into the gutter. His eyes have fallen; nobody looks at him: Doors have always been flung in his face, in his face. (CLARKE, 2001, p. 23) 
Sent to the "penatenrinary - the petty tyranny" (CLARKE, 2001, p. 24) for his crimes, the police guards goad him with their rifles, provoking him to attack them. Instead, Indigo remains meek and docile until one of the officers grows impatient and takes matters into his own hands: "one morning he was sitting with the Bible / and his head popped open; / his black scalp puffed up fatally scarlet" (CLARKE, 2001, p. 24).

Rue's drunken anger and frustration similarly elicits a revenge fantasy in which he attempts to defile white space:

I want to muck up their little white paradise here. I want to swat their faces til I'm comfortable in my gut. I want to give em all headaches and nausea: I'll play fortissimo Ellington, blacken icy whiteness. I'll draw blood the way Picasso draws nudes- voluptuously. (CLARKE, 2001, p. 32).

Rue here wishes to "mark" white space with his black stain, legitimate his black otherness in a space dominated by whites.

The transgressing black outlaw body answers to the expectations of a white majority that constructs him as other, as animalistic, drunken, murderous sexual predator. The murder is not only drunken opportunism but the result of centuries of oppression, as Rue says, "Here's how I justify my error: / The blow that slew Silver came from two centuries back. / It took that much time and agony to turn a white man's whip / into a black man's hammer" (CLARKE, 2001, p. 35). Because they are uneducated and speak "cankered English," they have become alienated from their own history. They have become transgressive criminals who are a threat to the white body politic, sullying the pure white snow with the red of crime. Their "blood-stained hands / must be legislated into grass (CLARKE, 2001, p. 39) by the authority of the Crown that invariably demands that "green slime scum over your black souls" (CLARKE, 2001, p. 39).

The ease with which white tourists traverse border spaces, their international mobility, is contrasted to the constricted spaces and reduced mobility which "errant" black bodies are allowed.

The "hanging niggers in Fredericton" (CLARKE, 2001, p. 41) become a public spectacle, a "theatrical ritual" (FOUCAULT, 1979, p. 14) of execution in which transgressive black bodies are excised from the community. They are rendered inhuman in the brutal plunge from the gallows, as the brothers' united bodies 
become a grotesque "strange fruit" hung "back-to-back in York County Gaol" (CLARKE, 2001, p. 12). ${ }^{4}$ The function of this "spectacle of the scaffold," as Foucault has demonstrated, is to "reveal the truth": "a successful public execution justified justice, in that it published the truth of the crime in the very body of the man to be executed" (FOUCAULT, 1979, p. 44). This macabre spectacle not only satisfies the mob's lust for retribution but enables a differentiation between docile white bodies and the transgressive bodies, grotesque bodies of black criminality. ${ }^{5}$ The hanging effectively expels the black aggressor from white space: "We'll be disjecta membra of Loyalist New Brunswick. We'll furiously spew up air as we fall. We'll try to eat your faces through our hoods. We'll plunge our bodies into pools of air, into coffins snug as our shadows, the shallow graves of mourning news." (CLARKE, 2001, p. 41).

Clarke seems to be suggesting here that the cousins do not go meekly to their deaths, for they attempt to "eat" the white faces that have condemned them with their rage. Just as blacks are denied a history, the newspaper reporters who wrote about the hanging could not see the men's faces, effectively de-humanizing them: "Barred from the interior of the gaol and scene of the double hanging, newsmen from a vantage point near the two-storey grey-stone building could see only the condemned men's shadows as they glided from the upper corridor and guyed down the stairs" (CLARKE, YEAR, p. 44).

The spaces that black bodies occupy in "Africadia" are abject ones: ramshackle homes, streets, back alleys, gallows, and graves. While they are regarded by the white majority as a threat to white space and racial "purity," it is the brothers who are most threatened by a spatial order which constructs them as errant and criminal, as modern-day runaway slaves. George Elliott claims bodies are

4 The jazz song Strange Fruit, sung by Billie Holiday, hauntingly evokes the suffering black body after it has been captured and lynched by the racist mobs of the American south. The "pastoral," which Clarke has argued is a clearly identifiable tradition in Africadian writing, is offset by the jarringly grotesque image of hanging black bodies: "Southern trees bear strange fruit/ Blood on the leaves and blood at the root/ Black bodies swinging in the southern breeze/ Strange fruit hanging from the poplar trees/ Pastoral scene of the gallows south/ The bulging eyes and the twisted mouth/ Scent of magnolia sweet and fresh/ Then the sudden smell of burning flesh/ Here is a fruit for the crows to pluck/ For the rain to gather, for the wind to suck/ For the sun to ripe, for the tree to drop/ Here is a strange and bitter crop."

5 Elizabeth Grosz suggests that society "carves meanings onto and out of bodies; it does not, as it professes, 'enlighten the masses' by reason and education but instead ensures its cohesion through coercion and cruelty. All cultures, all modes of civilization practice a kind of ritualized bodyinscription that is no more or less painful or primitive than in our own forms of initiation ceremonies" (GROSZ, 1995, p. 34). 
disciplined by the scrutiny of a white gaze threatened by their alterity, effaced from a history that disavows black presence in this country. The black body in Canadian space is therefore a suffering, abject body, rendered docile through the various strategies used to exclude it from the body politic. It is also rendered a passive, disciplined body penetrated by white racist discourse, "their scalpel eyes slicing into us, their shrapnel voices exploding our dreams, their heavy metal hands ripping into us - with a crabby penmanship that dates back to the Dark Ages" (CLARKE, 2001, p. 6).

\section{The "Polluting" Wessindian in Multicultural Toronto}

The black body "under scrutiny" reflects not only the realities of Canada's oldest black communities, but some of its newer ones as well. As Canada's largest urban centre, Toronto is the city in which more recent articulations of black identity have taken root. In her collection of short stories entitled Her Head a Village, Makeda Silvera represents the harsh realities of urban life for the Caribbean immigrants who come to Canada searching for a land of opportunity and social mobility, only to discover that they are forced to occupy liminal spaces in the city (in ghettos or back alleys, or as live-in domestics in white homes). Furthermore, they occupy a symbolic space "between" the first and third world, a postcolonial and transnational black spatial imaginary which effectively evacuates their "authentic" Caribbean blackness from the white space of Canada. Walcott points out that:

For black Canadians, living the in-between is conditioned by their inside / outside status in the nation-state; whether indigenous black or otherwise, in-betweenness in Canada is conditioned by a plethora of national narratives, from the idea of "two founding peoples," to multicultural policies, to immigration policies ... the simultaneity of being here and not being here is, in effect, an in- between position. The prospect of in-betweenness is, however, not only produced by the state: it is also something black folks have chosen through their multiple diasporic and outer-national political identifications. (WALCOTT, 2003, p. 48).

The construction of a Canadian spatial imaginary demands that the territory circumscribed by Canada's boundaries must be "protected," both physically and symbolically, from alien (and therefore threatening) others. This is particularly true 
of black bodies, for the black body brings with it a whole series of social and symbolic connotations (inferiority, defilement, criminality, irrationality), which threaten the privileged white body.

If the nation is figured as a collective body which expels or neutralizes the other as the abject, then the threshold between the inside and the outside of the body politic in Silvera's "Caribbean Chameleon" is located at the immigration desk at Pearson International Airport. It is here that the scoped regime differentiates between the docile, unthreatening white bodies of Canadian tourists returning from a sojourn in the "festive" islands of the Caribbean and the errant black bodies of immigrants and live-in domestics. Because black bodies are constructed as suspicious and criminal to whites, they are denied entry. The black body is positioned outside the threshold, scandalous in its attempts to import its third world blackness into first world whiteness. As Manning suggests, "despite that the discourse of generosity and benevolence prevails within the Canadian national imaginary," Erin Manning points out, "the categories of 'us' and 'them' remain standard practices at ports of entry” (MANNING, 2003, p. xvii).

The narrator is a Jamaican domestic worker returning to her job in suburban Toronto. Her rich Jamaican vocal rhythms, outward appearance, and attitude are reproduced through white tourist consumption. While their vestment suggests their facile appropriation of Jamaican cultural codes, attire, and attitude, they are "dressed to kill," (SILVERA, 1994, p. 28) suggesting the implicit role they play in the ostracization of the black body, symbol of her all-too-authentic Jamaican identity: "Tourists with straw baskets, suntan, skin peeling, rum-filled stomach, tang of jerk pork Boston-style. Lignum vitae carvings, calabash gourds, a piece of black coral, earrings out of coconut shell ... you can get anything, no problem, as long as there are U.S. dollars" (SILVERA, 1994, p. 27).

The souvenir trinkets that the white tourists bring back with them signal their consumer cannibalism and echo the cycles of exploitation in which black domestics are imported into white spaces for their cheap labour. They represent a form of anthropophagy in which a toned down, controlled, and domesticated version of Caribbean blackness is ingested and neutralized. As Manning suggests, "the contradictory longing both to possess and excrete the other without digesting the problematic effects of such a consumption reinforces a negation of the other as a historical subject-in-process, rendering the other a victim of imitation, a twodimensional object in a sea of whiteness" (MANNING, 2003, p. 70). 
The ease with which white tourists traverse border spaces, their international mobility, is contrasted to the constricted spaces and reduced mobility which "errant" black bodies are allowed. The gaze of the immigration officer creates the third world subject as trespasser: "JA customs officer has eyes deep in passport, behind desk, trying to figure out whether dis a banana boat passport or what" (SILVERA, 1994, p. 28), while white tourists are ignorant of the economic necessities which push Jamaicans toward Canada: "Ah, a well-spent vacation. Why do they want to leave?" (SILVERA, 1994, p. 28). When the Jamaican woman is asked the particulars of her trip, she is eyed with suspicion:

"Did you stay with family? "No mam, I visit dem, but I stay in a hotel." Suspicion. "Hotel?" "Yes mam." "Take off your glasses, please." Officer look lady in black polka dot pant suit up and down. "What date did you leave Canada for Jamaica?" Woman in black polka dot pant suit start breathing hard. "I have me landed papers right here." "Open your suitcase, please." Suitcase get search. Hand luggage search. Handbag search. Sweat running down woman black face. Line long behind her. Officer call for body search. Woman in black polka dot pant suit trembling. Head start itch. Line longer. Black and white in line. Woman in black polka dot pant suit sweating with embarrassment. (SILVERA, 1994, p. $31)$.

As the interrogation increasingly angers her, she loses her temper and the immigration officer becomes "frighten like hell" (SILVERA, 1994, p. 31) for "he don't understand the talking of tongues" (SILVERA, 1994, p. 31). Her heavy Jamaican accent and black skin are interpreted as signs of her irreducible otherness, while the invasion of her bodily space and the search through her personal effects are ways of controlling her and filtering out her threatening blackness. Rather than being seen as a normal response to the injustice of being treated unfairly, her outrage is seen by the immigration officers and the white tourists as mad spectacle - as the outward manifestation of the inward "savageness" of the unruly black woman: "Officer shout for Royal Canadian Mounted Police to take mad woman away. 'TAKE HER AWAY. TAKE HER AWAY,' Take this wild savage. Monster. Jungle Beast” (SILVERA, 1994, p. 32).

The African is equated to the jungle, to the barely human, and the theatricality of the scene strikingly demonstrates the dynamics of power and bodily identification at play in the crossing of protected boundary spaces. "Confronting 
the black race." Laporte writes, "the colonialist state faces the ultimate challenge: how to acknowledge its failure to master all things, while managing to keep its failure masked" (LAPORTE, 1993, p. 65).

In Silvera's "Canada Sweet, Girl," the Canadian spaces occupied by immigrant labourers and domestics are contrasted to the ease and spatial privilege of white suburbia. The protagonist awakens from a nightmare in which "men dress up in uniforms dragging me through the streets of Toronto to di Strathcona Hotel. I find miself wash up in cold sweat, mi hands trembling, head hurting and mi screaming" (SILVERA, 1994, p. 33). The protagonist lies in bed "like a corpse," finding it difficult to face her work day of menial labour. The transition to Toronto and the difficulty of being a domestic worker is seen as a curse or punishment: "I lay in bed, staring at di ceiling in my small one-bedroom asking what sin mi commit. What sins my mother or her mother commit? What is it we do that vex God so?" (SILVERA, 1994, p. 33).

If downtown Yonge Street is a space of spectacle and multicultural consumption in which black bodies do not particularly arouse suspicion, the protagonist's West Indian blackness is refused in the "clean" suburbs of the city where she seeks employment. Even the names of Toronto's suburbs seem to be unwelcoming to her: "Sometimes I take di bus to places that had names like Agincourt, Don Mills, Mississauga. One time I even go on a interview close to where Punsie live, a place called Pickering. Same answer everywhere, 'No Canadian experience' (SILVERA, 1994, p. 34). Unable to find work, she becomes a transient in the city, lacking money, a roof over her head, and legal papers. The immigrant black body becomes vagrant, belonging literally in no place: "To batter bout pon Toronto streets with no place to go no easy" (SILVERA, 1994, p. 36).

Bev, a waitress at the coffee shop in which the protagonist rests, finds her a job and invites her to stay at her place. But as an illegal immigrant, she has no access to the social safety net in Canada and is forced to live a precarious existence of subterfuge and silence: "I can't collect no unemployment insurance, I don't have no landed papers, so I have to prepare myself for di worse, if it come" (SILVERA, 1994, p. 38). When she learns of her mother's death in Jamaica, she cannot risk leaving Canada for she is an illegal immigrant, and therefore must "stay right here and mourn for Mama" (SILVERA, 1994, p. 41). She is rendered spatially immobile, trapped by her condition "between" Canada and Jamaica.

Black immigrants, domestic workers, and refugees in Silvera's Toronto not 
only occupy the underbelly of the city, but their physical mobility is defined by necessity. Welfare lines, food banks, and subway trains are the spaces that this nameless and silenced community trudges through in their daily grind for survival. In another short story titled "Welfare Line," refugees "adopt all kinds of name and identity to stay on" (SILVERA, 1994, p. 75) and are identified by a number, not by a proper name: “'You know we don't use workers' names. I need your worker's number.' Di girl mek mi feel like a damn fool” (SILVERA, 1994, p. 77). The subway becomes a descent into a purgatory when the protagonist, loaded with bundles of clothes and food from the welfare office and food bank, is looked at with derision by whites.

In a reversal of the mainstream construction of Canada as a "white space" peppered with multicultural colour, here Silvera presents whiteness as a suffocating hegemonic order, a defiling and overwhelming threat to black identity and corporeality. Furthermore, Jamaican oral tradition, coupled with an exhausted woman's desire to express her frustration and displeasure at living in poverty in Canada, is read by the white subway riders as madness:

The subway pack. People everywhere with big shopping bags Simpsons, Eaton's, the Bay all about. I get a seat eventually and sit down. Mi get tired of reading the ads on the train, and of the quiet. Our Christmas back home is boss, singing and jollification everywhere. The train is like a funeral home, so I start to open some of the packages they give me at the Children's Aid. All white dolls coming out of these packages. Everything white. White Barbie, white Ken. So mi begin to talk to miself about all this whiteness around me and in the bag. Some people in the train staring, but I don't care. After standing in the welfare line today I'm entitled to talk to myself. Is my garbage bag. Is my business. So let dem look with dem starchy face. (SILVERA, 1994, p. 80).

Anotherwriter ofCaribbean origin who presents the "body troubles"(SENNETT, 1994, p. ) of the nation is Austin Clarke. Not only is the "Wessindian" community which Clarke writes about socially and economically trapped within the city, it is threatened by a suffocating whiteness which renders it spatially immobile, suspect, and criminal. George Elliott Clarke has pointed out that Austin Clarke's protagonists see themselves as falsely persecuted, aristocratic figures whose precarious economic and social downfall may be attributed to the racist system in Canada which relegates them to the bottom of the social hierarchy: "Clarke's black 
immigrant characters are either would- be or used-to-be aristocrats. Their access to the status symbols of the WASP Canadian Establishment is frustrated by a polite, tight, white-iste caste system ... the move to Canada is a shock of class and social privilege, a bracing plunge into a lower standard of living" (CLARKE, 1995, p. 239-40).

Clarke constructs blackness through the careful staging of the black body in white Toronto, one whose excretions and olfactory "otherness" comes to symbolize both its visceral attachments to the Caribbean and its condition of abjection within white urban Canada. ${ }^{6}$ In a short story titled "Griff," for instance, the protagonist is "a black man from Barbados who sometimes denied he was black" (CLARKE, 2003, p. 99). Despite his "blasted black man" body, he put on the airs of British sophistication and the "civilized bearing that came with it" (CLARKE, 2003, p. 99). He enjoyed taking his wife out to the Cancer Calypso Club located in "the entrails of the city where pimps and doctors and lonely immigrants hustled women and brushed reputations in a brotherhood of illegal liquor" (CLARKE, 2003, p. 100). After a night of particularly ribald drinking and dance, he heads out into the city, riding in streetcars filled with white riders who "seemed to realize his blackness more intensely; white people looking at him hard - questioning his presence it seemed. It might be nothing more than the way his colour changed colour, going through a kaleidoscope of tints and shades under the varying ceiling lights of the street cars" (CLARKE, 2003, p. 101). ${ }^{7}$

This cannibalistic gaze and racial objectification is similar to that which Fanon experiences in his encounter with the white gaze: "sealed into that crushing objecthood, I turned beseechingly to others ... the attitudes, the glances of

6 Smell disturbs because it is associated with the residues of the body and with the transgressing of bodily (and ethnic) boundaries. Laporte suggests that "civilization despises odor and will oust it with increased ferocity as power strives to close the gap between itself and divine purity. This ferocity reaches its peak when imperialism punishes colour. Smells have no place in the constitutive triad of civilization: hygiene, order, and beauty. In the empire of hygiene and order, odor will always be suspect" (LAPORTE, 1993, p. 84).

7 Citing the experience of Franz Fanon (Black Skin White Masks, London: Pluto Press, 1967) as he walks down a street and is observed with fear and trepidation by a white child, Michael Keith and Nigel Thrift unpack the operations of embodied signification involved in such an encounter: "In the colonial situation Fanon dissects, the black man's visibility has a double effect: his skin allows him to be seen and marked as different (from whites), but it also separates him (from whites) in a way which makes him unknowable (to whites). As a strategy of colonial rule, the colonial master-subject separates and defines the colonial slave-subject, only to find that this makes the colonial slave-subject radically unknowable ... the exchanges between coloniser and colonised involve the ambivalence of desire and fear, the failure of not only identification and anti-identification, but also mutual misrecognition in the field of meaning, which amount to extraordinary efforts to police the boundaries between coloniser and colonised in and through the practice of power" (CLARKE, 2003, p. 43). 
the others fixed me there, in the sense in which a chemical solution is fixed by a dye" (FANON, 1967, p. 109). The attempts by white commuters to "fix" the black body into a stable, immobile abject otherness is contrasted remarkably to the "kaleidoscope of tints and shades" of Griff's black skin as it is traversed by a series of neon lights, suggesting that blackness is "fluid" and can be applied "like paint to anyone who lapses in class or morality" (CLARKE, 2002, p. 242). The changing shade of Griff's black skin may also suggest his own attempts to deny his blackness, to shed the negative connotations associated to his colour. Griff's attempts to elevate himself above his acquaintances at the Calypso Club particularly the almost blue-black Jamaican construction worker who dances with his wife, and the sense of himself as a British subject and its attendant privileges, suggest that blackness sits uneasily on his skin.

Despite the fact that he considers himself more British subject than black Barbadian immigrant, Griff is unable to stomach the fact that white eyes stare him down in public transit. In the course of his ruminations, he fantasises his own "whiteness", as follows:

To him, it was staring. And his British breeding told him that to look at a person you didn't know (except she was a woman) was infra dig. Infra dig was the term he chose when he told Clynn about these incidents of people staring at him on the streetcars. The term formed itself on his broad thin lips, and he could never get the courage to spit it at the white people staring at him. (CLARKE, 2003, p. 101).

Despite the fact that Griff senses that he is spatially constrained by white eyes, forced to exhibit his sweating, stinking blackness only within the underground confines of the Calypso Club, he nevertheless imposes similar spatial constraints on his wife. While he allows her to dance with other men at the club, he does so only insofar as it makes him seem a "good sport" to his bar mates. When his wife's public displays with a man blacker than himself infuriates Griff, he takes her outside the club and proceeds to calmly and brutally strangle her.

In another short story titled "The Man," the protagonist is an aging immigrant flâneur who wanders the streets of Toronto obsessively collecting newspaper clippings and writing letters to "greatmen and women around the world"(CLARKE, 2003 , p. 125), hoping he will make some small social or political impact in a world in which he has become peripheral. Each morning he leaves his apartment, that "centre of gravity from which he is spilled out at eight each morning" (CLARKE, 
2003, p. 122) and wanders among the ethnic shops of Kensington Market. Clarke configures the black body in urban space as one that transgresses physical and symbolic thresholds, be it in its peripatetic life in a white city, or in its corporeal smells and excretions which spill beyond its own bodily boundaries, thereby "polluting" the white space of an ostensibly multicultural Toronto.

If the Man is an urban flâneur, his idleness comes not from bourgeois comfort but from lack of employment. He is lonely and secretive, living "like a bat. Secret and self-assured and self- contained as an island, high above the others in a rooming house; cut off from people, sitting and writing his important letters" (CLARKE, 2003, p. 122). He is a pathetic dandy who walks the streets of the city observing and recording, unable to fully participate in the day-to-day economic realities that surround him. Hence, "when morning comes, at eight o'clock he hits the streets, walking in the same two square miles around his home, rummaging through libraries for British and American newspapers, for new words and ideas for letters" (CLARKE, 2003, p. 122).

One evening during one of his walks, the Man is spotted by a policeman on the street and is interpolated by him: "A policeman looked through the window of his yellow cruiser, stopped him in his wandering tracks, and said, "What the hell're you doing up here, boy" (CLARKE, 2003, p. 123). Because he found himself wandering into an area of the city that is both economically and socially unattainable to him, he is literally stopped in his tracks. His dishevelled black body is rendered criminal, a stain upon white middle class respectability."Git in! Git your black ass in here!” (CLARKE, 2003, p. 124). This "coded” language used by the policeman (FOSTER, 1996, p. 7) suggests the escaped slave narratives of the American South. Rather than being questioned about his reason for being in the area, the officer simply speeds off with his bewildered captive in his charge to Don Mills where he deposits him. The police officer thereby symbolically cleanses the white space of Forest Hill of the defilement represented by the protagonist's black body. "Many policing practices," Walcott writes, "situate blackness outside the nation as criminal, deviant other. At the same time, these policies work to contain blackness within the nation; because, as the argument goes, black bodies must be managed, policed and controlled" (WALCOTT, 2003, p. 123).

On his return home, the Man takes out his anger and frustration on his pillows, which he has carefully fashioned into the body of the policeman who had humiliated him: "It was soon after this that he became violent ... each morning at 
seven when he woke up, and late at night before he went to bed, after he washed his mouth out with salt water, he kicked the 'policeman'twice" (CLARKE, 2003, p. 124). Where white urban bodies in Toronto are marked by neutrality, black ones are marked with excess, with their all-too-visible blackness. The Man wanders into a rich neighbourhood of shops and boutiques and realizes suddenly that his body will undermine any attempts to remain invisible:

Once he dashed into Hold Renfrew. It was the last desperate haven. The water was heavy on his nerves, on his bladder. His eyes were red and watery. He barely had strength to speak his wish. Experience with this urge had cautioned him, as he stood before the glass case of ladies' silk underwear, that to open his mouth at that moment, when the association of this urge with ladies' panties was in full view, meant a relaxation of his grip on the water inside him. Then it would pour out onto the carpeted floor of Persian silence, perhaps even dribble onto the feet of the young clerk whose legs he could see beneath the thinness of her almost transparent dress. (CLARKE, 2003, p. 130).

In the confrontation with the sanitized white female body, the leaking black body is a contaminant which symbolically links back to the psycho-sexual dynamics of slaves and their white female owners and the sexual taboo arising from them: "The young woman saw his stiffness and posture, and with a smile and a wave, showed him the nearest haven" (CLARKE, 2003, p. 130). ${ }^{8}$

The Man is attracted to the seductive power of a well-turned phrase, and through his obsessive letter writing to prominent world leaders, he seeks to symbolically escape from the sweat and drudgery of manual labour in the sweatshops of his homeland. But it is his black body, not his ability with language, which fixes him and limits his mobility in the city, relegating him to the stalls of Kensington market.

Where language once signified an opportunity to escape sweat shop labour, in Canada it becomes ineffectual and useless, much like the bits of old paper stuck in his pockets, the bulging boxes of paper in his apartment, or the Chinese characters on street signs in Kensington market which remain mysterious to him.

8 George Elliott Clarke has pointed out that in Austin Clarke's stories, "women, whiteness, and hence, white women symbolize attractive, glistening surfaces that can entrap and destroy the unwary, meaning, for Clarke, black male immigrants ... Clarke creates protagonists who view white women as symbols of Canada - that is to say, of a vamp who entices 'her' thralls with phony promises of bourgeois comfort" (CLARKE, 1995, p. 243). 
Rather than celebrating the visual display of black bodies and black culture "when others filled the streets and danced in a Caribana festival and wore colours hot as summer in a new spring of life" (CLARKE, 2003, p. 128), he chooses to remain true to language and "cut[s] himself off from those frivolous, ordinary pleasures of life that had surrounded his streets for years" (CLARKE, 2003, p. 128). If the Man is critical of the festive black body that metaphorically links to narratives of a slave corporeality devoid of language, the white majority embraces such carnivalesque public display for they do not overtly challenge white spatial and social hegemony. The Man is thus located on the outside of the university system (CLARKE, 2003, p. 128) just as he is spatially segregated outside the tony neighbourhoods of middle and upper class Toronto. His body betrays him to white eyes in its fleshy corpulent excess but also in its ethnic excess. Nevertheless, it is in the darkest recess of his litter-strewn apartment the attempts to hide the evidence of his own corporeality:

He was safe inside his room. Relieved and safe. He did it in the pail. He keeps this pail in a corner, under a table, on which is a two-ringed hotplate. In times of urgency he uses it, and in times of laziness and late at night. He adds soap flakes to the steaming liquid to hide its smell and composition, and when he carries the plastic pail down, the woman on welfare cannot smell or detect his business. (CLARKE, 2003, p. 130).

The Man is a collector of urban refuse, the yellowed pages of his notes and the newspaper clippings in his apartment are placed in contradistinction to the limitations of black corporeality in a white city. The objects that surround him seem to echo and mock his debased situation. Pacing in his apartment, he seeks out bits of information among the scattered books and papers that are stored in "plastic bags imprinted with barely visible names of stores and shops" (CLARKE, 2003, p. 132). Seizing upon one bag, he remarks the faded label on it, that of the Dominion supermarket where he purchases his meagre provisions. "Dominion" activates a symbolic language in which the black body straddles both the former British colonies of the West Indies and Canada's "Queen City." He removes his clothing, peeling off layers of sweaters as though they were layers of skin: "He takes off his jacket. It is two sizes too large. Then he takes off his red woolen sweater; and another one of cotton, and long-sleeved; and then a third, grey, long-sleeved, round-necked and marked PROPERTY OF THE ATHLETIC 
DEPARTMENT UNIVERSITY OF TORONTO.” (CLARKE, 2003, p. 133).

The irony of his de-vestment lies in the fact that he will never have access to the university, let alone work there. But he willingly participates in this "ownership" of his body, for he so values that which represents the legitimating knowledge represented by the University that he turns a blind eye to the ironies of wearing such a garment: "He is a man of words, and the printed claim of ownership on his third pullover never ceases to amaze and impress him" (CLARKE, 2003, p. 133).

The Man suffers from "literary constipation" (CLARKE, 2003, p. 133), often praying "for an easier movement of words from the bowels of his brain" (CLARKE, 2003, p. 133). This striking inversion of bodily functions signals the "body troubles" typical of societies intent on disavowing bodily specificity and difference. The Man attempts to wash away his "ethnic stench" and attain that summit of words and ideas of which the university, the jumble of papers, and the letters to world leaders are but examples. Also, the official stationary he receives in response to his inquiries to "great personage[s]" in Britain and the West Indies becomes fetishized: "He continues to feel the paper between big thumb and two adjoining fingers, rubbing and rubbing and feeling a kind of orgasm coming on" (CLARKE, 2003, p. 135). His writing implements come to symbolize his black identity, the noir of the "PARKER SUPER QUINK INK. PERMANENT BLACK" momentarily reversing the denigration which the word conferred upon him throughout his life: "He likes the noir of the ink he uses, as he liked the noir in the Nugget which gave his shoes longer life and made them immortal and left its proud, industrious, and indelible stain on his fingers" (CLARKE, 2003, p. 136). But unable to sustain his own self- illusion, he decides to overturn the hotplate in his room, for "fire cleans everything" (CLARKE, 2003, p. 137). In burning down his prison-like apartment, the Man metaphorically effaces his polluting blackness from white Toronto.

\section{Conclusion}

The black body in Canadian urban space is either disavowed (much as the long history of slavery in this country has been disavowed), or treated as a threat that must be managed, policed, or rendered harmless through the celebration of the non-threatening, festive black body. If the discourse of multicultural inclusiveness 
promises economic opportunities and a better future for its Caribbean immigrants, the economic necessities of urban survival in Toronto and its systemic social inequalities make for a nightmarish urban landscape for its black immigrants. For the black community in Halifax, Africville is described in terms of garbage and disease, an abject space on the peripheries of a white city that eventually comes to be associated with black identity itself. As Rinaldo Walcott has suggested, "writing blackness" has been difficult in Canada, for black communities have continually been socially and spatially excluded and marginalized" (WALCOTT, 2003, p. 120).

\title{
Solo sagrado: exclusão espacial e o corpo negro urbano
}

\begin{abstract}
Resumo
Este artigo incide sobre a exclusão sofrida pelas comunidades negras no Canadá, desde os tempos coloniais. As políticas segregacionistas impostas pelos colonizadores brancos endossavam, entre outros fatores, os temores de tocar, a impureza e a corrupção da pureza racial, o que agravou a exclusão espacial e social das comunidades negras. De fato, o discurso colonialista hegemônico correlaciona frequentemente a cor preta e o abjeto, associando a negritude com as excreções corporais. Um exemplo é o bairro negro de Africville, onde espaços precários têm sido atribuídos aos corpos negros. Pode-se dizer que o imaginário espacial canadense é uma construção convencional, visando à exclusão de todas as ameaças ao corpo branco privilegiado. Exemplos de críticas às práticas de desumanização geradas por tais políticas proliferam nas obras literárias de Austin Clarke, George Elliott Clarke e Makeda Silvera, nas quais propõe-se a construção de um corpo negro no espaço urbano canadense.
\end{abstract}

Palavras-chave: Literatura afro-canadense. Negritude. Africville. Exclusão espacial. Corpo negro urbano.

\section{Bibliography}

ANSAY, Pierre, SCHOONBRODT, R. eds. Penser la ville: Choix de textes philosophiques. Brussels: Éditions des archives d'architecture moderne, 1989.

ASHCROFT, Bill, GRIFFITHS, G., TIFFIN, H. "Introduction." The PostColonial Studies Reader. Ed. B. Ashcroft, G. Griffiths, and H. Tiffin. New York: Routledge, 1995. 
ASHCROFT, Bill, GRIFFITHS, G., TIFFIN, H. Post-Colonial Studies: The Key Concepts. New York: Routledge, 2001.

BACHELARD, Gaston. La poétique de l'espace. Paris: Presses Universitaires de France, 1964.

BAILLY, Antoine. Représenter la ville. Paris: Economica, 1995.

BAKER, Alan, BIGER. G. Ideology and Landscape in Historical Perspective: Essays on the Meanings of Places in the Past. Cambridge: Cambridge University Press, 1992.

BARTHES, Roland. "Sémiologie et urbanisme." Architecture aujourd'hui, v. 152 (1970), pp. 11-13.

BURMAN, Jenny. "At the Scene of the Crossroads, 'Somewhere in this Silvered City’: Diasporic Public Spheres in Toronto.” Public v. 22 / 23, pp. 195-202.

CAVELL, Richard. "Theorizing Canadian Space: Postcolonial Articulations." Canada: Theoretical Discourse / Discours théoriques. Selected Proceedings, Theoretical Discourse and the Canadian Intellectual Community Conference. Saint-Jovite, Québec, 1992. Eds. Terry Goldie, Carmen Lambert, and Rowland Lorimer. Association for Canadian Studies, 1994, pp. $75-104$.

CHANADY, Amaryll. "La spatialisation de l'histoire dans la narration.” L'espace en toutes lettres. Eds. Rachel Bouvet and Basma Omari. Montréal: Éditions Nota Bene, 2003, pp. 53-73.

CLAIRMONT, Donald H., MAGILL, Dennis William. Africville: The Life and Death of a Canadian Black Community. Toronto: McClelland and Stewart, 1974.

CLARKE, Austin. Choosing His Coffin: The Best Stories of Austin Clarke. Toronto: Thomas Allen Publishers, 2003.

CLARKE, George Elliott. Execution Poems. Wolfville, Nova Scotia: Gaspereau Press, 2001.

CLARKE, George Elliott. Fire on the Water: An Anthology of Black Nova Scotian Writing: Vol.2. Lawrencetown Beach, Nova Scotia: Pottersfield Press, 1995.

CLARKE, George Elliott. "Campbell Road Church." Fire on the Water. Lawrencetown Beach, Nova Scotia: Pottersfield Press, 1995, pp. 146-147. 
CLARKE, George Elliott. "Salvation Army Blues." Fire on the Water. Lawrencetown Beach, Nova Scotia: Pottersfield Press, 1995, p. 150.

CLARKE, George Elliott. Odysseys Home: Mapping African-Canadian Literature. Toronto: University of Toronto Press, 2002.

CLIFFORD, J. “Travelling Cultures.” Cultural Studies. Eds L. Gossberg, C. Nelson and P. Treichler. London: Routledge, 1992.

DECERTEAU, Michel. The Production of Space. Trans. Donald NicholsonSmith. Oxford: Blackwell Publishing, 1991.

DE DIEGO, Rosa. Les villes de la mémoire. Montréal: Humanitas, 1997.

DELEUZE, Gilles, GUATTARI, F. "Qu'est-ce qu'une littérature mineure?" Kafka: pour une littérature mineure. Paris: Minuit, 1975, pp. 29-50.

DeleuZE, Gilles, GUATTARI, F. A Thousand Plateaus - Capitalism and Schizophrenia. Trans. B. Massumi. London: Athalone Press, 1988.

DUNCAN, James, LEY, D., eds. Place / Culture / Representation. London: Routledge, 1993.

FANON, Frantz. Black Skin White Masks. New York: Grove Press, 1967.

FERGUSON, Priscilla Parkhurst. "The Flâneur On and Off the Streets of Paris." The Flâneur. Ed. Keith Tester. New York: Routledge, 1994, pp. 22-42.

FIAMENGO, Janice. "Regionalism and Urbanism." The Cambridge Companion to Canadian Literature. Ed. Eva-Marie Kröller. Cambridge: Cambridge University Press, 2004, pp. 241-262.

FOSTER, Cecil. A Place Called Heaven: The Meaning of Being Black in Canada. Toronto: Harper Perennial Canada, 1996.

FOUCAULT, Michel. “Of Other Spaces.” Diacritics, v.16.1(1986), pp. 22-27.

FOUCAULT, Michel. Discipline and Punish: The Birth of the Prison. Trans. Alan Sheridan. New York: Vintage Books, 1979.

FOUCAULT, Michel. The Order of Things: An Archaeology of the Human Sciences. New York: Random House, 1970.

GILBERT, Helen. "Black and White and Re(a)d All Over Again: Indigenous Minstrelsy in Contemporary Canadian and Australian Theatre." Theatre Journal, v. 55 (2003), pp. 679-698.

GILLOCH, Graeme. Myth and Metropolis: Walter Benjamin and the City. Cambridge: Blackwell Press, 1996. 
GOLDBERG, David. Racist Culture: Philosophy and the Politics of Meaning. Oxford: Blackwell, 1993.

GOULD, Peter, WHITE, R. Mental Maps. Boston: Allen and Unwin, 1986.

GREGORY, Derek. Geographical Imaginations. Cambridge: Blackwell Publishers, 1994.

GROSZ, Elizabeth. Space, Time, and Perversion. New York: Routledge, 1995.

HARBISON, Robert. Eccentric Spaces. New York: Knopf, 1977.

HARVEY, David. Spaces of Hope. Los Angeles: University of California Press, 2000.

HESSE, Barnor. "Black to Front and Black Again: Racialization Through Contested Times and Spaces." Place and the Politics of Identity. Eds. Michael Keith and Steve Pile. London: Routledge, 1993, pp. 162-182.

HISS, Tony. The Experience of Place. New York: Vintage Books, 1991.

HOLIDAY, Billie. "Strange Fruit.” By Lewis Allan. Lady in Autumn. New York: Polygram, 1991.

HOOKS, Bell. Yearning: Race, Gender, and Cultural Politics. Toronto: Between the Lines, 1990.

HUGGAN, Graham. "Decolonizing the Map." The Post-Colonial Studies Reader. Eds. Bill Ashcroft, Gareth Griffiths, Helen Tiffin. New York: Routledge, 1995, pp. 407-411.

HUTCHEON, Linda. The Politics of Postmodernism. London: Routledge, 1989. ITWARU, Arnold Harrichand. The Invention of Canada: Literary Text and the Immigrant Imaginary. Toronto: Tsar, 1990.

JACOBS, Jane. The Death and Life of Great American Cities. New York; Vintage Books, 1961.

JARVIS, Brian. Postmodern Cartographies: The Geographical Imagination in Contemporary American Culture. London: Pluto Press, 1998.

JAYE, Michael C., WATTS, A.C., eds. Literature and the Urban Experience: Essays on the City and Literature. New Brunswick, N.J.: Rutgers University Press, 1981.

KEITH, Michael, PILE, S., Eds. Place and the Politics of Identity. New York: Routledge, 1993. 
KRISTEVA, Julia. Powers of Horror: An Essay on Abjection. New York: Columbia University Press, 1991.

KRISTEVA, Julia. Étrangers à nous-mêmes. Paris: Gallimard, 1988.

KRÖLLER, Eva-Marie. “The City as Metaphor.” Canadian Literature, v. 169 (2001), pp. 5-10.

LAPORTE, Dominique. History of Shit. Trans. Nadia Benabid and Rodolphe elKhoury. Cambridge, Mass.: MIT Press, 1993.

LYNCH, Kevin. The Image of the City. Cambridge, Mass.: M.I.T. Press, 1960.

MACLENNAN, Hugh. Two Solitudes. Toronto: Macmillan, 1986.

MANNING, Erin. Ephemeral Territories: Representing Nation, Home, and Identity in Canada. Minneapolis: University of Minnesota Press, 2003.

MARTINEZ, Jill. "An Interview with George Ryga." Journal of Canadian Fiction, v. 35-35. (1986), pp. 106-121.

MASSEY, Doreen. Space, Place, and Gender. Minneapolis: University of Minnesota Press, 1994.

MITCHELL, Don. Cultural Geography: A Critical Introduction. Malden, Mass.: Blackwell Publishers, 2000.

MOHANRAM, Radhika. Black Body: Women, Colonialism, and Space. Minneapolis: University of Minnesota Press, 1999.

MUMFORD, Lewis. The City in History. New York: Harcourt and Brace, 1961.

NELSON, J. "The Space of Africville: Creating, Regulating, and Remembering the "Urban Slum." Race, Space, and the Law: Unmapping White Settler Society. Ed. Sherene Razack. Toronto: Between the Lines, 2002, pp. 211-232.

NEW, W.H. A History of Canadian Literature. Montréal and Kingston: McGillQueen's University Press, 2003.

NEW, W.H. Borderlands: How We Talk About Canada. Vancouver: UBC Press, 1998.

NEW, W.H. Land Sliding: Imagining Space, Presence, and Power in Canadian Writing. Toronto: University of Toronto Press, 1997.

PACHE, Walter. "Urban Writing." Encyclopedia of Literature in Canada. Ed. W.H. New. Toronto: University of Toronto Press, 2002, pp. 1148-1156. 
PIKE, Burton. The Image of the City in Modern Literature. Princeton, N.J.: Princeton University Press, 1981.

PILE, Steve, THRIFT, N. Mapping the Subject: Geographies of Cultural Transformation. London: Routledge, 1995.

RAZACK, Sherene. "Introduction: When Place Becomes Race." Race, Space, and the Law: Unmapping White Settler Society. Ed. Sherene Razack. Toronto: Between the Lines, 2002.

RYBCZYNSKI, Witold. City Life: Urban Expectations in a New World. Toronto: Harper Collins, 1995.

SAID, Edward. Orientalism. New York: Random House, 1978.

SANDERS, Leslie. "Anti-Modern Spaces: African Canadians in Nova Scotia." Floating the Borders: $\quad$ New Contexts in Canadian Criticism. Ed. Nurjehan Aziz. Toronto: Tsar, 1999, pp. 106-121.

SAUNDERS, Charles R. “A Visit to Africville.” Fire on the Water. Lawrencetown Beach, Nova Scotia: Pottersfield Press, 1995, pp. 53-65.

SENNETT, Richard. Flesh and Stone: The Body and the City in Western Civilization. New York: Norton and Company, 1994.

SIBLEY, David. Geographies of Exclusion: Society and Difference in the West. London: Routledge, 1995.

SILVERA, Makeda. Her Head a Village and Other Stories. Vancouver: Press Gang Publishers, 1994.

SIMMEL, Georges. "The Metropolis and Mental Life." On Individuality and Social Forms. Chicago: University of Chicago Press, 1971.

SOJA, Edward. Postmodern Geographies: The Reassertion of Space in Critical Social Theory. London: Verso, 1989.

WALCOTT, Rinaldo. Black Like Who? Writing Black Canada. Toronto: Insomniac Press, 2003.

WALKER, James. “African-Canadians.” Encyclopedia of Canada's Peoples. Ed. Paul Robert Magocsi. Toronto: University of Toronto Press, 1999, pp. 139-176.

WARD, Frederick. "Mary." Fire on the Water. Lawrencetown Beach, Nova Scotia: Pottersfield Press, 1995, p. 17.

WARD, Frederick. "Dialogue \# 1." Fire on the Water. Lawrencetown Beach, Nova Scotia: Pottersfield Press, 1995, pp. 18-19. 
WATSON, Sophie, GIBSON, K., eds. Postmodern Cities and Spaces. Oxford: Blackwell, 1995.

WEIMER, David R. The City as Metaphor. New York: Random House, 1966.

WELTON, Donn. "Introduction: Situating the Body." Body and Flesh: A Philosophical Reader. Ed. Donn Welton. Oxford: Blackwell, 1998, pp. 1-8.

WESLEY-DESMOND, Gloria. "Jump the Broom." Fire on the Water. Lawrencetown Beach, Nova Scotia: Pottersfield Press, 1995, pp. 69-70.

WESLEY-DESMOND, Gloria. "Back Alley Tramp." Fire on the Water. Lawrencetown Beach, Nova Scotia: Pottersfield Press, 1995, pp. 66-67.

WHITLOCK, Gillian. "The Bush, the Barrack-Yard and the Clearing: 'Colonial Realism' in the Sketches and Stories of Susanna Moodie, C. L. R. James and Henry Lawson.” The Journal of Commonwealth Literature, v. 20.1 (1985), pp. $33-48$.

WILLIAMS, Rosalind. Notes on the Underground: An Essay on Technology, Society, and the Imagination. Cambridge, Mass.: MIT Press, 1992.

WILSON, Elizabeth. The Sphinx in the City: Urban Life, the Control of Disorder, and Women. London: Virago, 1991.

WOODS, David. Native Song: Poetry \& Paintings. Halifax: Nimbus Pub Ltd, 2008 .

YORK. Lorraine. "Home Thoughts or Abroad? A Rhetoric of Place in Modern and Postmodern Canadian Political Poetry." Canadian Literature, v. 51-52 (1994), pp. 321-339.

Recebido em 06/06/2016

Aceito em 05/09/2016 